\title{
Metabolomics Application in Maternal-Fetal Medicine
}

\author{
Vassilios Fanos, ${ }^{1}$ Luigi Atzori, ${ }^{2}$ Karina Makarenko, ${ }^{3}$ \\ Gian Benedetto Melis, ${ }^{4}$ and Enrico Ferrazzi ${ }^{3}$ \\ ${ }^{1}$ NICU, Puericulture Institute and Neonatal Section, AOU and University of Cagliari, 09124 Cagliari, Italy \\ ${ }^{2}$ Department of Biomedical Science, University of Cagliari, 09124 Cagliari, Italy \\ ${ }^{3}$ Department of Woman, Mother and Neonate, Buzzi Hospital, Biomedical and Clinical Sciences School of Medicine, \\ University of Milan, 20122 Milan, Italy \\ ${ }^{4}$ Department of Obstetrics and Gynecology and Human Reproduction Physiopathology, University of Cagliari, \\ 09124 Cagliari, Italy
}

Correspondence should be addressed to Enrico Ferrazzi; enrico.ferrazzi@unimi.it

Received 19 April 2013; Revised 10 May 2013; Accepted 13 May 2013

Academic Editor: Kaei Nasu

Copyright (C) 2013 Vassilios Fanos et al. This is an open access article distributed under the Creative Commons Attribution License, which permits unrestricted use, distribution, and reproduction in any medium, provided the original work is properly cited.

\begin{abstract}
Metabolomics in maternal-fetal medicine is still an "embryonic" science. However, there is already an increasing interest in metabolome of normal and complicated pregnancies, and neonatal outcomes. Tissues used for metabolomics interrogations of pregnant women, fetuses and newborns are amniotic fluid, blood, plasma, cord blood, placenta, urine, and vaginal secretions. All published papers highlight the strong correlation between biomarkers found in these tissues and fetal malformations, preterm delivery, premature rupture of membranes, gestational diabetes mellitus, preeclampsia, neonatal asphyxia, and hypoxic-ischemic encephalopathy. The aim of this review is to summarize and comment on original data available in relevant published works in order to emphasize the clinical potential of metabolomics in obstetrics in the immediate future.
\end{abstract}

\section{Introduction}

Metabolomics (or metabonomics) is the youngest and possibly the most promising among "omics technologies." It represents a holistic approach to the metabolites that constitute a cell, tissue, or organism [1]. It is able to provide a phenotypic fingerprinting of a cell, tissue, or organism by virtue of its ability to measure multiple metabolites directly from complex biological systems. Any molecule less than $1 \mathrm{kDa}$ in mass can be sorted out by metabolomics technology as a single final product of active/inactive genes in a given condition (genome), its activation (mRNA transcriptome), the setup of enzymatic machineries (proteome), and their actual biological processes.

Metabolomic studies in pregnancy are not a novel concept. Since the 1960s, the role of specific single metabolites in the dynamic interactions among fetus, placenta, and pregnant woman had been reported in various studies [2-6]. However, metabolomics in pregnancy, under present highthrough-output technologies, is still an "embryonic" science: in 2009 , the first review on this topic had been published based on limited data [1], the state of art situation has not changed much since then except for the fact that recent studies prove again and again the immense possibilities of this technology in the complex field of pregnancy where two partner organisms are interacting for mutual benefit $[5,7-11]$.

\section{The Metabolomic Approach}

The metabolomic approach consists of two sequential phases. The analytical phase is designed to profile all low molecular weight metabolites in a given biological specimen to generate an all-inclusive spectrum. Possible sources of biological tissues that can be exploited in pregnancy are both from the mother (plasma, urine, vaginal fluids, milk), the fetus (amniotic fluid, umbilical cord blood), and the newborn (plasma, urine, placenta, saliva, other fluids). Different technologies might be generally adopted: nuclear magnetic resonance (NMR) spectroscopy, gas chromatography-mass spectrometry (GC-MS), and liquid chromatography-mass spectrometry 
(LC-MS). The phase of data analysis and interpretation requires highly complex data mining software and an ample database of metabolites to describe the nodes and networking of metabolic pathways [7, 8, 12-27]. In a recent paper, we described in detail these phases in studies performed in pregnant women and neonates [25].

\section{Metabolomics in Plasma of Pregnant Women}

To the best of our knowledge, metabolomic analysis performed on plasma of pregnant women had been reported in eight studies [2, 7, 8, 18, 26-29] addressing different pregnancy complications. Plasma samples were analyzed with NMR or LC-MS. Main results of these studies are reported in Table 1 .

Lower plasma betaine and trimethylamine-N-oxide concentrations [18] were observed in maternal plasma in case of fetal malformation. Additional different significant findings were reported for amino acids involved in gluconeogenesis, for cis-aconitate, acetone, 3-hydroxybutyrric, and hypoxanthine. These data suggest that the malformed fetuses demand enhanced gluconeogenesis and tricarboxylic acids cycle (Krebs Cycle), possibly due to hypoxic metabolism. Significant differences were observed also between normal pregnancies and cases which would later develop gestational diabetes. Changes in 3-hydroxyisovalerate and 2hydroxyisobutirrate were observed, suggesting early changes in biotin status and altered aminoacid and/or gut metabolism. Preeclampsia (PE) had been a major focus in metabolomics technologies applied to maternal-fetal medicine. Both Kenny et al. [26] and Odibo et al. [27] focused their studies on predicting preeclampsia. Kenny's work was mainly focused on late preeclampsia of maternogenic origin, as we can argue from the limited prevalence of small for gestational age (SGA) newborns in his cohort, and early and late PE were not objects of a different analysis. Odibo in a slightly smaller sample observed a lower detection rate for early onset preeclampsia only. Unfortunately, the lack of consistent classification of hypertensive disorder in pregnancy as regards the relationship between early onset preeclampsia and late onset preeclampsia and placental vascular damage [17] might impact adversely the correlations observed in the metabolome in cases with and cases without early placental vascular damage and fetal growth restriction (FGR) [9].

Very recently Bahado-Singh et al. [7, 8] published 2 papers focusing on early onset and late onset preeclampsia, selected by the calendar based definition of early and late preeclampsia and by evidence of placental damage in early onset preeclampsia. NMR-based metabolomic analysis was performed on first-trimester maternal serum at 11-13 weeks of gestation to assess the possible prediction of late preeclampsia. A parsimonious genetic computing model proved yielded $60 \%$ sensitivity at $96.6 \%$ specificity for late preeclampsia prediction. A comparison with database of the previous study on early onset preeclampsia proved a strong separation of late-versus early-onset preeclampsia groups. Two metabolites based on the VIP plot were notable for their differences between preeclamptic and normal pregnant women: glycerol and carnitine. Glycerol and carnitine are both important for lipid metabolism and mitochondrial energy productions based on lipids. More significantly carnitine inhibits oxidative stress. All these metabolic pathways are overexpressed in metabolic syndrome and its acute expression in late preeclampsia.

\section{Metabolomics in Urine of Pregnant Women and Neonates}

Table 2 reports the relevant methodology, results, and conclusions of five studies investigation metabolomics findings in urine of pregnant women and neonates [30-34]. In pregnant women with fetuses affected by somatic abnormalities metabolomics findings confirmed enhanced plasmatic concentration of glucogenic amino acids as well as an increase in hypoxanthine concentration and tricarboxylic acid cycle suggesting ATP degradation and fetal stress.

A possible role of methionine, phenylalanine, histidine, and hexose (possibly glucose) changes in preterm delivery has been suggested.

Inositol phosphoglycan P type (P-IPG) has been linked to insulin resistance, thus making its raise an important marker in Gestational Diabetes Mellitus (GDM) evaluation, fetal growth alterations, and preeclampsia prediction.

Generic markers of prenatal disorders, such as preeclampsia, hypoxia, chromosomal disorders, or prediagnostic GDM, are N-methyl-2-pyridone-5-carboxamide and N-methylnico tinamide (products of abnormal nucleotide meta bolism) most likely increasing due to the effects of stress.

In a recent paper by Diaz and coworkers [18], maternal plasma and urine were collected and analysed with NMR. Metabolic alterations observed in maternal biofluids in pregnancies with fetal malformations, chromosomal disorders, GDM, PPROM, and preterm delivery suggest potential use of metabolomics in identifying women at risk of prenatal and maternal pregnancy-related disorders. The study by Dessì and coworkers on neonatal urine demonstrated the potential of metabolomics in identifying FGR foetuses and contributing to their clinical management [34] with metabolomics analysis of neonatal urine being another promising field for further investigation $[19,20,35]$. In a preliminary study by our group, a metabolomic approach on maternal urine was used for the diagnosis of labor, suggesting that it is possible to anticipate the timing of delivery [36].

\section{Metabolomics in Amniotic Fluid}

Metabolomic analysis of amniotic fluid, mainly determined with NMR and MS (ULPC and LC), has been reported by several studies addressing different pregnancy complications $[3,30,37-41]$. Main results of these studies are presented in Table 3.

Amniotic fluid biomarkers seemed to have the best predictive value for malformed fetuses; in this case, lower glucose and higher free lactate levels indicate that energy 
Table 1: Methodology, findings, and main conclusions derived from metabolomics studies on maternal plasma.

\begin{tabular}{|c|c|c|c|c|c|c|}
\hline Population & $\begin{array}{l}\text { Gestational age } \\
\text { at examination }\end{array}$ & $\begin{array}{l}\text { Metabolomic } \\
\text { analysis }\end{array}$ & $\begin{array}{l}\text { Main differences in } \\
\text { abnormal pregnancies }\end{array}$ & $\begin{array}{l}\text { Significance/take-home } \\
\text { messages }\end{array}$ & Reference & Author, year \\
\hline $\begin{array}{l}20 \text { normal } \\
\text { pregnancies }\end{array}$ & Matched & & & & & \\
\hline $\begin{array}{l}27 \text { fetal } \\
\text { malformations }\end{array}$ & At diagnosis & & $\begin{array}{l}\text { Gluconeogenetic } \\
\text { aminoacids, cis-aconitate, } \\
\text { acetone, 3-hydroxibutirric, } \\
\text { hypoxanthine }\end{array}$ & $\begin{array}{l}\text { Pregnant women with } \\
\text { malformed fetus showed } \\
\text { enhanced glucogenesis and } \\
\text { tricarboxylic acids cycle }\end{array}$ & & \\
\hline $\begin{array}{l}23 \text { chromosomal } \\
\text { disorders }\end{array}$ & At diagnosis & NMR & & & [18] & $\begin{array}{l}\text { Diaz et al., } \\
2011\end{array}$ \\
\hline $\begin{array}{l}14 \text { prediagnostic } \\
\text { GDM }\end{array}$ & $\begin{array}{l}\text { Before positive } \\
\text { OGTT }\end{array}$ & & $\begin{array}{l}\text { 3-Hydroxyisovalerate, } \\
\text { 2-hydroxyisobutirrate }\end{array}$ & $\begin{array}{l}\text { Pregnant women who later } \\
\text { develop GDM showed early } \\
\text { changes in biotin status and } \\
\text { altered aminoacid and/or } \\
\text { gut metabolism }\end{array}$ & & \\
\hline $18 \mathrm{pPROM}$ & At diagnosis & & No alterations & & & \\
\hline $\begin{array}{l}1 \text { normotensive } \\
\text { pregnancies } \\
\text { versus } 11 \\
\text { preeclamptic } \\
\text { pregnancies }\end{array}$ & n.r. & NMR & $\begin{array}{l}\text { Hystidine, tyrosine, } \\
\text { phenylalanine }\end{array}$ & $\begin{array}{l}\text { Diagnosis of preeclampsia } \\
\text { was possible by } \\
\text { metabolomics }\end{array}$ & {$[28]$} & $\begin{array}{l}\text { Turner et al., } \\
2008\end{array}$ \\
\hline $\begin{array}{l}60 \text { cases of PE } \\
\text { versus matched } \\
\text { controls }\end{array}$ & $15 \pm 1$ weeks & UPLC-MS & $\begin{array}{l}40 \text { metabolites (detection } \\
\text { rate } 71 \%, 5 \% \text { false positive) }\end{array}$ & $\begin{array}{l}\text { Metabolomics might } \\
\text { predict preeclampsia, early } \\
\text { and late PE not analysed } \\
\text { separately }\end{array}$ & {$[26]$} & $\begin{array}{l}\text { Kenny et al., } \\
2010\end{array}$ \\
\hline $\begin{array}{l}41 \text { cases of } \mathrm{PE} \\
\text { versus controls }\end{array}$ & First trimester & LS/MS & $\begin{array}{l}40 \text { acylcarnitine species } \\
\text { and } 32 \text { aminoacids } \\
(\text { AUC-ROC }=0.85)\end{array}$ & $\begin{array}{l}\text { Metabolomics might } \\
\text { predict early onset PE }\end{array}$ & {$[27]$} & $\begin{array}{l}\text { Odibo et al., } \\
2011\end{array}$ \\
\hline $\begin{array}{l}30 \text { cases of early } \\
\text { PE versus } 60 \\
\text { controls }\end{array}$ & First trimester & NMR & $\begin{array}{l}\text { Citrate, glycerol, } \\
\text { hydroxyisovalerate, and } \\
\text { methionine and uterine } \\
\text { Doppler abnormal PI } \\
\text { (detection rate of } 82.6 \% \text {, at } \\
\text { an FPR of } 1.6 \% \text { ) }\end{array}$ & $\begin{array}{l}\text { Metabolomics might } \\
\text { predict early onset PE }\end{array}$ & {$[7]$} & $\begin{array}{l}\text { Bahado- } \\
\text { Singh et al., } \\
2012\end{array}$ \\
\hline $\begin{array}{l}30 \text { cases of late } \\
\text { PE versus } 119 \\
\text { controls }\end{array}$ & First trimester & NMR & 17 metabolites & $\begin{array}{l}\text { Metabolomics might } \\
\text { predict late onset PE }\end{array}$ & {$[8]$} & $\begin{array}{l}\text { Bahado- } \\
\text { Singh et al., } \\
2013\end{array}$ \\
\hline $\begin{array}{l}\text { Pregnant } \\
\text { women who } \\
\text { subsequently } \\
\text { delivered an } \\
\text { SGA baby } \\
\end{array}$ & First trimester & UPLC-MS & $\begin{array}{l}19 \text { metabolites }(\mathrm{OR}=44 \text {; } \\
\text { AUC-ROC }=0.90)\end{array}$ & $\begin{array}{l}\text { Metabolomics might } \\
\text { predict SGA }\end{array}$ & [29] & $\begin{array}{l}\text { Horgan et al., } \\
2011\end{array}$ \\
\hline
\end{tabular}

GDM: gestational diabetes mellitus; pPROM: preterm premature rupture of membranes; OGTT: oral glucose tolerance test; NMR: nuclear magnetic resonance spectroscopy; PE: preeclampsia; UPLC-MS: ultra performance liquid chromatography-mass spectrometry; LS/MS: liquid chromatography-mass spectrometry; SGA: small for gestational age.

production is being conducted preferentially through glycolysis under anaerobic (hypoxic) conditions and a reduced use of mitochondrial respiratory chain pathway (reflected by succinate increase). Due to hypoxia less glucose is available to other tissues and in order to replenish the glucose level an augmented glucose production via gluconeogenesis is observed (with a resulting decrease in gluconeogenic amino acids levels).

Higher glutamine level, glutamine/glutamate ratios, increase in glycoprotein P1, and lower urea level reflect kidney disorders/underdevelopment. Changes in glycine, serine, $\alpha$ oxoisovalerate, leucine, and ascorbate suggest a disturbance in amino acid biosynthesis. Amniotic fluid changes described above are characteristic for the whole group of malformations indicating changes in glycolysis, gluconeogenesis, and kidney underdevelopment.

Data regarding GDM (increase of glucose level consistent with previously reported insulin increase; slight reduction of several amino acids, creatinine, acetate, formate, glycerophosphocholine) suggest changes in amino acids biosynthesis, higher demand for protein, and changes in lipid metabolism, and renal function. 
TABLE 2: Methodology, findings, and main conclusions derived from metabolomics studies on maternal and neonatal urine.

\begin{tabular}{|c|c|c|c|c|c|c|}
\hline Population study & $\begin{array}{l}\text { Gestational age } \\
\text { at examination }\end{array}$ & $\begin{array}{l}\text { Metabolomic } \\
\text { analysis }\end{array}$ & Main results & $\begin{array}{l}\text { Significance/take-home } \\
\text { messages }\end{array}$ & Reference & Author, year \\
\hline $\begin{array}{l}48 \text { GDM cases versus } \\
23 \text { controls }\end{array}$ & $\begin{array}{l}\text { Third } \\
\text { trimester }\end{array}$ & MS & $\begin{array}{l}\text { Increased urinary } \\
\text { excretion of P-IPG, } \\
\text { positive correlation with } \\
\text { blood glucose }\end{array}$ & $\begin{array}{l}\text { Metabolomic } \\
\text { identification of P-IPG is } \\
\text { a potential marker of } \\
\text { insulin resistance, may } \\
\text { predict fetal growth } \\
\text { alterations in GDM } \\
\text { patients }\end{array}$ & {$[33]$} & $\begin{array}{l}\text { Scioscia et al., } \\
2007\end{array}$ \\
\hline $\begin{array}{l}9 \text { PE cases versus } 84 \\
\text { controls }\end{array}$ & $\begin{array}{l}\text { First } \\
\text { trimester }\end{array}$ & $\begin{array}{l}\text { Elisa-based } \\
\text { assay }\end{array}$ & $\begin{array}{l}\text { Rapid raise of P-IPG } \\
\text { (sensitivity and } \\
\text { specificity of } 88.9 \% \text { and } \\
62.7 \% \text {, resp.) }\end{array}$ & $\begin{array}{l}\text { Metabolomics by } \\
\text { multiple assessment of } \\
\text { samples might predict } \\
\text { preeclampsia }\end{array}$ & {$[32]$} & $\begin{array}{l}\text { Paine et al., } \\
2010\end{array}$ \\
\hline $\begin{array}{l}3083 \text { pregnancies } \\
\text { positive to the } \\
\text { screening of } \\
\text { Smith-Lemli-Opitz } \\
\text { syndrome }\end{array}$ & $\begin{array}{l}\text { Second } \\
\text { trimester }\end{array}$ & GC/MS & $\begin{array}{l}\text { 16 } \alpha \text {-OH-DHEA, urine } \\
\text { total estriol. Fetal steroid } \\
\text { sulfatase deficiency } 98 \% \\
\text { detection rate, } 95 \% \text { CI } \\
92-99\end{array}$ & $\begin{array}{l}\text { Metabolomics analysis of } \\
\text { Maternal urine steroids } \\
\text { is effective in detecting } \\
\text { STSD. Possible use for } \\
\text { diagnosing ADHD and } \\
\text { CGDS (common in } \\
\text { association with STSD) }\end{array}$ & {$[31]$} & $\begin{array}{l}\text { Marcos et al., } \\
2009\end{array}$ \\
\hline $\begin{array}{l}75 \text { pregnancies ( } 13 \\
\text { healthy) }\end{array}$ & & & & $\begin{array}{l}\text { Potential of the tandem } \\
\text { use of MS and NMR for }\end{array}$ & & \\
\hline 13 fetal malformations & & & Hippurate, amino acids & metabolomics studies of & & \\
\hline $\begin{array}{l}20 \text { predisposition to } \\
\text { GDM }\end{array}$ & $\begin{array}{l}\text { Second } \\
\text { trimester }\end{array}$ & $\begin{array}{l}\text { UPLC-MS } \\
\text { NMR }\end{array}$ & No relevant changes & $\begin{array}{l}\text { urine and amniotic fluid } \\
\text { in pregnant women }\end{array}$ & {$[30]$} & $\begin{array}{l}\text { Graça et al., } \\
2012\end{array}$ \\
\hline 6 preterm delivery & & & $\begin{array}{l}\text { Methionine, } \\
\text { phenylalanine, hystidine, } \\
\text { hexose (possibly } \\
\text { glucose) }\end{array}$ & & & \\
\hline $\begin{array}{l}26 \text { preterm FGR } \\
\text { versus } 30 \text { preterm } \\
\text { appropriate for } \\
\text { gestational age }\end{array}$ & Neonates & ${ }^{1} \mathrm{H}$ NMR & $\begin{array}{l}\text { Myoinositol, sarcosine, } \\
\text { creatine, and creatinine }\end{array}$ & $\begin{array}{l}\text { Metabolomics might } \\
\text { identify FGR and } \\
\text { contribute to the clinical } \\
\text { management of FGR } \\
\text { neonates }\end{array}$ & {$[34]$} & $\begin{array}{l}\text { Dessì et al., } \\
2011\end{array}$ \\
\hline
\end{tabular}

GDM: gestational diabetes mellitus; MS: mass spectrometry; P-IPG: inositol phosphoglycan P type; PE: preeclampsia; GC/MS: gas chromatography-mass spectrometry; STSD: steroid sulfatase deficiency; ADHD: attention deficit-hyperactivity disorder; CGDS: contiguous gene deletion syndrome; UPLC-MS: ultra performance liquid chromatography-mass spectrometry; NMR: nuclear magnetic resonance spectroscopy; ${ }^{1} \mathrm{H}$ NMR: proton nuclear magnetic resonance spectroscopy; FGR: fetal growth restriction.

A derangement of amino acid metabolism due to observed increase in succinic acid and glutamine concentration and significantly lower concentrations of creatine and creatinine has been suggested for the spina bifida cases analyzed with metabolomics techniques.

The changes observed in the amniotic fluid related to preterm delivery include increase of allantoine (a marker of oxidative stress) and a decrease of myoinositol that promotes fetal lung maturation.

Two recent cross-sectional metabolomics studies reported the importance of the amniotic fluid metabolic signature for preterm labor (PTL) with or without intra-amniotic infection or inflammation (IAI) $[3,41]$. Amniotic fluid biomarkers were able to discriminate 3 groups based on the pregnancy outcome [41]: (1) patients with PTL who delivered at term, (2) patients with PTL without IAI who delivered preterm, and (3) patients PTL with IAI who delivered preterm (characterized by an increase in amino acid metabolites). A reduction of carbohydrates in the amniotic fluid was associated with preterm delivery (with or without IAI). Methyladenine and diaminopimelic acid, components of bacterial processes and bacterial wall, respectively, were the most significant biomarkers in this clinical condition.

These studies show the potential of human amniotic fluid metabolome analysis as the basis for the development of rapid tests to differentiate between patients at risk of impending preterm birth (with or without infection/inflammation) and patients who will deliver at term.

\section{Metabolomics in Placenta}

Metabolomic analysis of placenta has been reported in several scientific papers $[4-6,10,11]$. The results of these studies are presented in Table 4. 


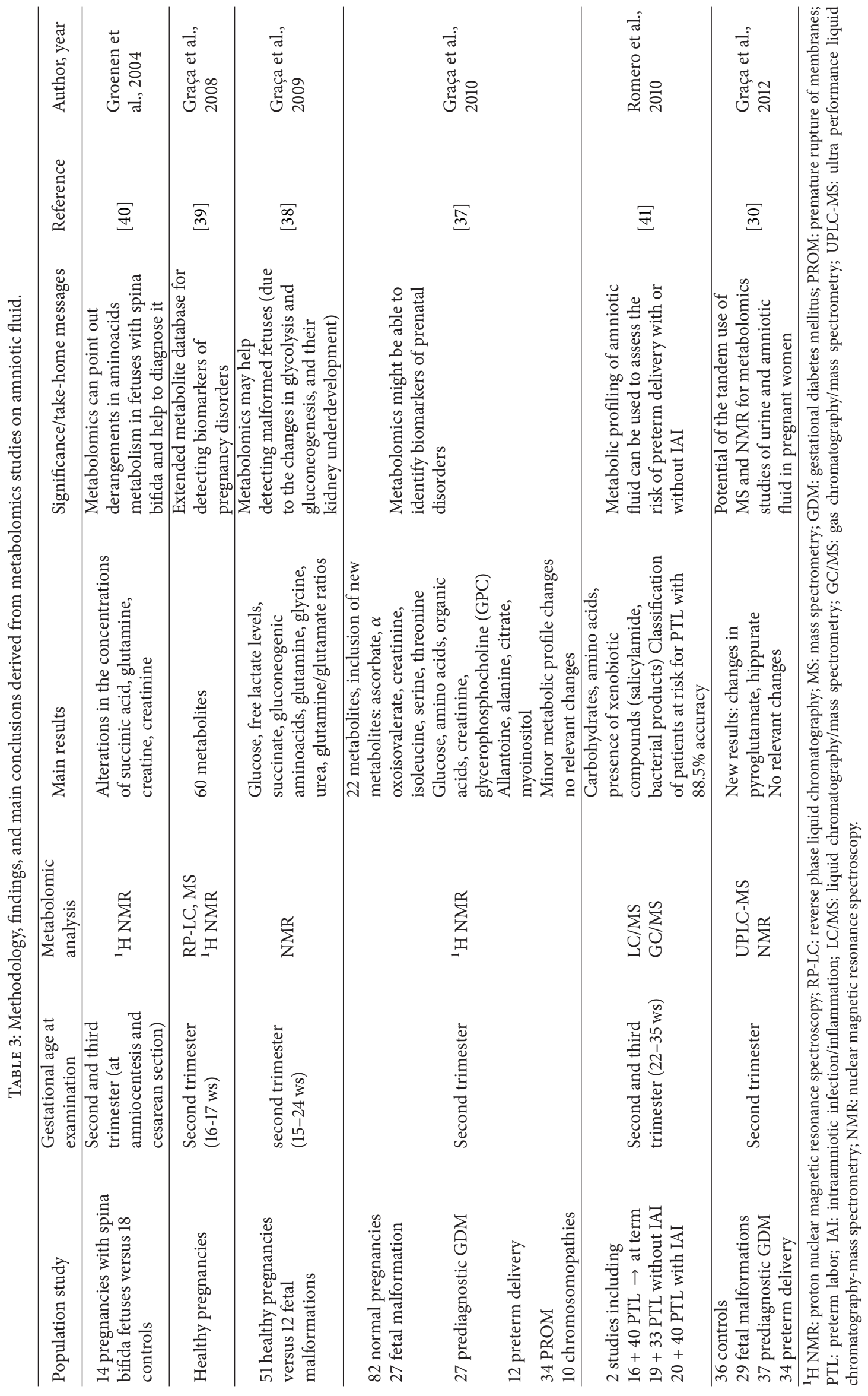


TABle 4: Methodology, findings, and main conclusions derived from metabolomics studies on placenta tissues.

\begin{tabular}{|c|c|c|c|c|c|c|}
\hline Population study & Material & $\begin{array}{l}\text { Metabolomic } \\
\text { analysis }\end{array}$ & Main results & $\begin{array}{l}\text { Significance/take- } \\
\text { home } \\
\text { messages }\end{array}$ & Reference & Author, year \\
\hline $\begin{array}{l}9 \text { SGA cases } \\
\text { versus } 8 \text { controls }\end{array}$ & $\begin{array}{l}\text { Placenta } \\
\text { villous } \\
\text { explants }\end{array}$ & UPLC-MS & $\begin{array}{l}574 \text { metabolites were significantly } \\
\text { different between SGA and } \\
\text { controls; } 49 \% \text { of metabolites of } \\
\text { interest were the same for SGA } \\
\text { explant cultured under hypoxic } \\
\text { conditions and controls cultured } \\
\text { under normoxic conditions } \\
\text { Changes in phospholipids, } \\
\text { essential amino acids (tryptophan, } \\
\text { methionine, and phenylalanine) } \\
\text { concentrations }\end{array}$ & $\begin{array}{l}\text { Metabolomics might } \\
\text { predict SGA }\end{array}$ & [11] & $\begin{array}{l}\text { Horgan et al., } \\
2010\end{array}$ \\
\hline $\begin{array}{l}11 \text { uncomplicated } \\
\text { term pregnancies }\end{array}$ & $\begin{array}{l}\text { Placenta } \\
\text { villous } \\
\text { explants }\end{array}$ & GC-MS & $\begin{array}{l}\text { Cultured in } 1 \%, 6 \% \text {, and } 20 \% \\
\text { oxygen. Differences in } \\
\text { 2-deoxyribose, threitol/erythritol, } \\
\text { hexadecanoic acid }\end{array}$ & $\begin{array}{l}\text { Metabolomics can be } \\
\text { applied to placenta } \\
\text { studies and could help } \\
\text { in detecting hypoxia }\end{array}$ & {$[10]$} & $\begin{array}{l}\text { Heazell et al., } \\
2008\end{array}$ \\
\hline $\begin{array}{l}6 \text { cases of } \\
\text { preeclampsia } \\
\text { versus } 6 \text { controls }\end{array}$ & $\begin{array}{l}\text { Villous } \\
\text { trophoblast }\end{array}$ & UPLC-MS & $\begin{array}{l}47 \text { metabolites in } \\
\text { preeclampsia-derived media } \\
\text { cultured under normoxic } \\
\text { conditions showed similarities to } \\
\text { that of uncomplicated pregnancies } \\
\text { cultured under hypoxic } \\
\text { conditions. Alterations in } \\
\text { glutamate and glutamine, } \\
\text { leukotrienes and prostaglandins, } \\
\text { kynurenine metabolism }\end{array}$ & $\begin{array}{l}\text { Metabolomics might } \\
\text { predict preeclampsia } \\
\text { of placental origin } \\
\text { developed due to } \\
\text { hypoxia }\end{array}$ & {$[4]$} & $\begin{array}{l}\text { Dunn et al., } \\
2009\end{array}$ \\
\hline $\begin{array}{l}8 \text { cases of } \\
\text { labor/Cesarean } \\
\text { section at } 3100 \mathrm{~m} \\
\text { versus } 8 \text { controls } \\
\text { with } \\
\text { labor/Cesarean } \\
\text { section delivery at } \\
\text { sea level }\end{array}$ & Placenta & $\begin{array}{l}{ }^{1} \mathrm{H} \text { NMR, } \\
{ }^{31} \mathrm{P} \text { NMR }\end{array}$ & $\begin{array}{l}\text { At sea level: metabolic markers of } \\
\text { oxidative stress, increased } \\
\text { glycolysis, elevated cholesterol, } \\
\text { and free amino acids. At } 3100 \mathrm{~m} \text { : } \\
\text { metabolic profiles with adaptation } \\
\text { to chronic hypoxia, decreased } \\
\text { reliance on anaerobic glycolysis; } \\
\text { presence of concentrations of } \\
\text { stored energy potential } \\
\text { (phosphocreatine), antioxidants } \\
\text { (taurine, inositol), and low free } \\
\text { amino acid concentrations }\end{array}$ & $\begin{array}{l}\text { Metabolomics might } \\
\text { help identify subjects } \\
\text { under hypoxic stress } \\
\text { (chronic hypoxic } \\
\text { preconditioning state } \\
\text { versus acute } \\
\text { ischemic/hypoxic } \\
\text { insult) }\end{array}$ & {$[6]$} & $\begin{array}{l}\text { Tissot van } \\
\text { Patot et al., } \\
2010\end{array}$ \\
\hline
\end{tabular}

SGA: small for gestational age; UPLC-MS: ultra performance liquid chromatography-mass spectrometry; GC-MS: gas chromatography-mass SPECTROMETRY; ${ }^{1} \mathrm{H}$ NMR: proton nuclear magnetic resonance spectroscopy; ${ }^{31} \mathrm{P}$ NMR: phosphorus nuclear magnetic resonance spectroscopy.

Dunn and coworkers [4] studied the metabolomic response of the normal and preeclamptic placental tissue to different oxygen levels. Placental tissue from uncomplicated pregnancies cultured in $1 \%$ oxygen (hypoxia) showed metabolic similarities to explants from late-onset preeclampsia pregnancies cultured at $6 \%$ oxygen (normoxia) thus suggesting an important role of hypoxia in preeclampsia development. Specific metabolic alterations included lipids, glutamate, glutamine, and metabolites related to tryptophan, leukotrienes, and prostaglandins. These metabolic changes were confirmed by Horgan and coworkers [11] that in a similar study compared placental features seen in small for gestational age (SGA) cases versus controls. Placental tissue from both groups was cultured in $1 \%, 6 \%$, and $20 \%$ oxygen. There was a significant difference in more than 500 metabolites between SGA and normal pregnancies at different oxygen tensions, while $49 \%$ of metabolites of interest were similar under normoxic conditions suggesting in vivo adjustment to hypoxia by SGA fetus, with a further consideration that normal oxygen level could worsen metabolic dysfunction of the placenta of a SGA fetus. This study reinforces the role of hypoxia and oxidative stress in preeclampsia and SGA. The role of chronic hypoxia was also studied by Tissot van Patot and colleagues [6], who reported the placentas at $3100 \mathrm{~m}$ sea level, naturally present higher concentrations of stored energy potential, antioxidants, and lower free amino acid 
concentrations, with better resistance to hypoxia and less evident metabolic stress response, and their results suggesting adaptation to chronic hypoxia in placenta at high altitude.

\section{Metabolomics in Vaginal Secretion}

A pilot mass spectrometry metabolomic study of women who had a spontaneous preterm birth compared to controls was conducted using the uterine cervical length as a selective factor. Noninvasive collection of cervicovaginal secretions from 15 women (women with a short cervix who had a spontaneous preterm birth compared to a control cohort with a short cervix and with a long cervix) was performed, and 17 markers of interest were identified. This particular metabolomic approach may help in the management of women at highrisk for spontaneous preterm birth [16].

\section{Metabolomics in Cord Blood}

Metabolomic analysis of cord blood has been carried out on samples collected from low birth weight (LBW) newborns, very low birth weight (VLBW) newborns, newborns diagnosed with FGR, SGA during pregnancy, newborns with asphyxia, and hypoxic ischemic encephalopathy. The results were reported in five studies [29, 42-45]. In the paper by Ivorra and coworkers [42] seven metabolites were able to discriminate a specific LBW metabolome, with a significant positive correlation between birth weight and proline, glutamine, free choline and negative correlation with citrulline and phenylalanine levels. These findings demonstrate the differences in the anabolic rate of the LBW newborns and the possible consequences that these metabolites' modifications can exercise on the newborn's health (e.g., maternal choline and its metabolite betaine supply modifying fetal histone and DNA methylation). It is also noteworthy that these changes were observed in the newborns only and not in their mothers, suggesting possible involvement of impaired placental transport of amino acids. Metabolic findings described above reveal the potential of metabolomics in identifying the population at risk. Tea and coworkers [43], analysing the cord blood from VLBW infants, demonstrated that a number of metabolites (glucose, acetate, lipids, pyruvate, glutamine, valine, threonine,) vary depending on gestational age at delivery. In the study by Favretto and coworkers [44], FGR presented changes in 22 metabolites with the most evident modifications in the following aminoacids composition: phenylalanine, tryptophan, and glutamate with 91-100\% sensitivity and $85-89 \%$ specificity. Cut-off values for phenylalanine and tryptophan were identified. This study demonstrates that metabolomics is a promising tool for identification of FGR fetuses.

Horgan and coworkers [29] observed that 19 metabolites (including sphingolipids, phospholipids, carnitines) differentiate SGA from controls, providing a base for a valid screening test for presymptomatic SGA or FGR. Early identification of cases at risk would help to develop adequate clinical management of patients to avoid serious complications. Another study that confirms one more time the importance of metabolomic analysis for the future of the medicine, in this case producing a robust predictive model for detecting encephalopathy in the newborns at 24 hours of life, in order to be able to provide the best timely treatment for the young patient is that of Walsh and coworkers [45]. This study found 29 metabolites among amino acids, acylcarnitines and glycerophospholipids to be significantly different in neonates with hypoxic ischaemic encephalopathy (HIE) versus controls or asphyxia versus controls groups, with 5 metabolites ( 2 acylcarnitines, 1 glycerophospholipid and 2 aminoacids) clearly delineating the severity of asphyxia and the degree of HIE.

All these data suggest that metabolomics is a noninvasive promising novel way of investigation, with the goal of understanding better the pathogenesis of different diseases, developing screening tests and helping in clinical management of the patients.

\section{Conclusions}

Metabolomics appears to be one of the most promising novel tools in obstetrics, among other important "omics". A recently published paper was entitled "Can biofluids metabolic profiling help us to improve health care during pregnancy?" [46]. The answer is "probably yes" if all these preliminary data on the potential usefulness of biofluids metabolomics in perinatal disorders are further investigated, single diseases are targeted and results are confirmed.

Through the metabolome we can observe the enormous and complex interactions between mother, placenta, and fetus. This high throughput technology might allow us to identify key role nodes for prediction, diagnosis, and monitoring of different obstetrics conditions.

\section{References}

[1] R. P. Horgan, O. H. Clancy, J. E. Myers, and P. N. Baker, "An overview of proteomic and metabolomic technologies and their application to pregnancy research," BJOG, vol. 116, no. 2, pp. 173-181, 2009.

[2] P. C. Woodham, T. O’Connell, J. Grimes et al., "Metabolomics to predict severe preeclampsia in early pregnancy," American Journal of Obstetrics and Gynecology, vol. 206, no. 1, supplement, p. S348, 2012.

[3] C. W. Beecher, "Metabolomic studies at the start and end of the life cycle," Clinical Biochemistry, vol. 44, no. 7, pp. 518-519, 2011.

[4] W. B. Dunn, M. Brown, S. A. Worton et al., "Changes in the Metabolic Footprint of Placental Explant-Conditioned Culture Medium Identifies Metabolic Disturbances Related to Hypoxia and Pre-Eclampsia," Placenta, vol. 30, no. 11, pp. 974-980, 2009.

[5] A. E. P. Heazell, M. Brown, S. A. Worton, and W. B. Dunn, "Review: the effects of oxygen on normal and pre-eclamptic placental tissue-insights from metabolomics," Placenta, vol. 32, supplement 2, pp. S119-S124, 2011.

[6] M. C. Tissot van Patot, A. J. Murray, V. Beckey et al., "Human placental metabolic adaptation to chronic hypoxia, high altitude: hypoxic preconditioning," American Journal of Physiology-Regulatory Integrative and Comparative Physiology, vol. 298, no. 1, pp. R166-R172, 2010. 
[7] R. O. Bahado-Singh, R. Akolekar, R. Mandal et al., "Metabolomics and first-trimester prediction of early-onset preeclampsia," Journal of Maternal-Fetal and Neonatal Medicine, vol. 25, no. 10, pp. 1840-1847, 2012.

[8] R. O. Bahado-Singh, R. Akolekar, R. Mandal et al., "Firsttrimester metabolomic detection of late-onset preeclampsia," American Journal of Obstetrics and Gynecology, vol. 208, no. 1, pp. 58.e1-58.e7, 2013.

[9] E. Ferrazzi, T. Stampalija, and J. E. Aupont, "The evidence for lateonset preeclampsia as a maternogenic disease of pregnancy," Fetal and Maternal Medicine Review, vol. 24, no. 1, pp. 18-31, 2013.

[10] A. E. P. Heazell, M. Brown, W. B. Dunn et al., "Analysis of the Metabolic Footprint and Tissue Metabolome of Placental Villous Explants Cultured at Different Oxygen Tensions Reveals Novel Redox Biomarkers," Placenta, vol. 29, no. 8, pp. 691-698, 2008.

[11] R. P. Horgan, D. I. Broadhurst, W. B. Dunn et al., "Changes in the metabolic footprint of placental explant-conditioned medium cultured in different oxygen tensions from placentas of small for gestational age and normal pregnancies," Placenta, vol. 31, no. 10, pp. 893-901, 2010.

[12] R. Antonucci, L. Atzori, L. Barberini, and V. Fanos, "Metabolomics: the "new clinical chemistry" for personalized neonatal medicine," Minerva pediatrica, vol. 62, no. 3, supplement 1, pp. 145-148, 2010.

[13] T. J. Athersuch, "The role of metabolomics in characterizing the human exposome," Bioanalysis, vol. 4, no. 18, pp. 2207-2212, 2012.

[14] L. Atzori, R. Antonucci, L. Barberini, J. L. Griffin, and V. Fanos, "Metabolomics: a new tool for the neonatologist," Journal of Maternal-Fetal and Neonatal Medicine, vol. 22, no. 3, pp. 50-53, 2009.

[15] L. Atzori, L. Barberini, M. L. Santoru, R. Antonucci, and V. Fanos, "Metabolomics explained to perinatologists and pediatricians," Journal of Maternal-Fetal and Neonatal Medicine, vol. 25, supplement 5, pp. 10-12, 2012.

[16] C. Auray-Blais, E. Raiche, R. Gagnon, M. Berthiaume, and J. C. Pasquier, "Metabolomics and preterm birth: what biomarkers in cervicovaginal secretions are predictive of high-risk pregnant women?" International Journal of Mass Spectrometry, vol. 307, no. 1-3, pp. 33-38, 2011.

[17] G. J. Burton, A. W. Woods, E. Jauniaux, and J. C. P. Kingdom, "Rheological and Physiological Consequences of Conversion of the Maternal Spiral Arteries for Uteroplacental Blood Flow during Human Pregnancy," Placenta, vol. 30, no. 6, pp. 473-482, 2009.

[18] S. O. Diaz, J. Pinto, G. Graça et al., "Metabolic biomarkers of prenatal disorders: an exploratory NMR metabonomics study of second trimester maternal urine and blood plasma," Journal of Proteome Research, vol. 10, no. 8, pp. 3732-3742, 2011.

[19] V. Fanos, R. Antonucci, L. Barberini, and L. Atzori, "Urinary metabolomics in the newborn and infants," Advances in Clinical Chemistry, vol. 58, pp. 193-223, 2012.

[20] V. Fanos, R. Antonucci, L. Barberini, A. Noto, and L. Atzori, "Clinical application of metabolomics in neonatology," Journal of Maternal-Fetal and Neonatal Medicine, supplement 1, pp. 104-109, 2012.

[21] V. Fanos, R. Antonucci, M. Zaffanello, and M. Mussap, "Neonatal drug induced nephrotoxicity: old and next generation biomarkers for early detection and management of neonatal drug-induced nephrotoxicity, with special emphasis on uNGAL and on metabolomics," Current Medical Chemistry, vol. 19, no. 27, pp. 4595-4605, 2012.

[22] V. Fanos, L. Atzori, A. Dessì, E. D’Aloja, G. Finco, and G. Faa, "The kidney in post-asphyctic syndrome: state of the art", in Developmental Nephrology: From Embryology To Metabolomics, V. Fanos, R. L. Chevalier, G. Faa, and L. Cataldi, Eds., Hygeia Press, 2011.

[23] V. Fanos, L. Barberini, R. Antonucci, and L. Atzori, "Metabolomics in neonatology and pediatrics," Clinical Biochemistry, vol. 44, no. 7, pp. 452-454, 2011.

[24] V. Fanos, L. Barberini, R. Antonucci, and L. Atzori, "Pharmametabolomics in Neonatology: is it a Dream or a Fact?" Current Pharmaceutical Design, vol. 18, no. 21, pp. 2996-3006, 2012.

[25] V. Fanos, M. Mussap, A. Noto, and L. Atzori, "Metabolomics in perinatology: where are we now?" Acta Medica Portuguesa, supplement 2, pp. 117-120, 2012.

[26] L. C. Kenny, D. I. Broadhurst, W. Dunn et al., "Robust early pregnancy prediction of later preeclampsia using metabolomic biomarkers," Hypertension, vol. 56, no. 4, pp. 741-749, 2010.

[27] A. O. Odibo, K. R. Goetzinger, L. Odibo et al., "First-trimester prediction of preeclampsia using metabolomic biomarkers: a discovery phase study," Prenatal Diagnosis, vol. 31, pp. 990-994, 2011.

[28] E. Turner, J. A. Brewster, N. A. B. Simpson, J. J. Walker, and J. Fisher, "Aromatic amino acid biomarkers of preeclampsiaa nuclear magnetic resonance investigation," Hypertension in Pregnancy, vol. 27, no. 3, pp. 225-235, 2008.

[29] R. P. Horgan, D. I. Broadhurst, S. K. Walsh et al., "Metabolic profiling uncovers a phenotypic signature of small for gestational age in early pregnancy," Journal of Proteome Research, vol. 10, no. 8, pp. 3660-3673, 2011.

[30] G. Graça, B. J. Goodfellow, A. S. Barros et al., "UPLC-MS metabolic profiling of second trimester amniotic fluid and maternal urine and comparison with NMR spectral profiling for the identification of pregnancy disorder biomarkers," Molecular Biosystems, vol. 8, no. 4, pp. 1243-1254, 2012.

[31] J. Marcos, W. Y. Craig, G. E. Palomaki et al., "Maternal urine and serum steroid measurements to identify steroid sulfatase deficiency (STSD) in second trimester pregnancies," Prenatal Diagnosis, vol. 29, no. 8, pp. 771-780, 2009.

[32] M. A. Paine, M. Scioscia, P. J. Williams, K. Gumaa, C. H. Rodeck, and T. W. Rademacher, "Urinary inositol phosphoglycan P-type as a marker for prediction of preeclampsia and novel implications for the pathophysiology of this disorder," Hypertension in Pregnancy, vol. 29, no. 4, pp. 375-384, 2010.

[33] M. Scioscia, S. Kunjara, K. Gumaa, P. McLean, C. H. Rodeck, and T. W. Rademacher, "Urinary excretion of inositol phosphoglycan P-type in gestational diabetes mellitus," Diabetic Medicine, vol. 24, no. 11, pp. 1300-1304, 2007.

[34] A. Dessì, L. Atzori, A. Noto, V. Fanos et al., "Metabolomics in newborns with intrauterine growth retardation (IUGR): urine reveals markers of metabolic syndrome," Journal of MaternalFetal and Neonatal Medicine, vol. 24, supplement 2, pp. 35-39, 2011.

[35] V. Fanos, J. van den Anker, A. Noto, M. Mussap, and L. Atzori, "Metabolomics in neonatology: fact or fiction?" Seminars in Fetal \& Neonatal Medicine, vol. 18, no. 1, pp. 3-12, 2013.

[36] A. Meloni, P. Caboni, F. Manconi et al., "Metabolomic approach to diagnosis of labour," Abstract International Congress of Obstetrics, vol. 119, supplement 1, pp. 1-250, 2012. 
[37] G. Graça, I. F. Duarte, A. S. Barros et al., "Impact of prenatal disorders on the metabolic profile of second trimester amniotic fluid: a nuclear magnetic resonance metabonomic study," Journal of Proteome Research, vol. 9, no. 11, pp. 6016-6024, 2010.

[38] G. Graça, I. F. Duarte, A. S. Barros et al., "1H NMR based metabonomics of human amniotic fluid for the metabolic characterization of fetus malformations," Journal of Proteome Research, vol. 8, no. 8, pp. 4144-4150, 2009.

[39] G. Graça, I. F. Duarte, B. J. Goodfellow et al., "Metabolite profiling of human amniotic fluid by hyphenated nuclear magnetic resonance spectroscopy," Analytical Chemistry, vol. 80, no. 15, pp. 6085-6092, 2008.

[40] P. M. W. Groenen, U. F. Engelke, R. A. Wevers et al., "Highresolution $1 \mathrm{H}$ NMR spectroscopy of amniotic fluids from spina bifida fetuses and controls," European Journal of Obstetrics Gynecology and Reproductive Biology, vol. 112, no. 1, pp. 16-23, 2004.

[41] R. Romero, S. Mazaki-Tovi, E. Vaisbuch et al., "Metabolomics in premature labor: a novel approach to identify patients at risk for preterm delivery," Journal of Maternal-Fetal and Neonatal Medicine, vol. 23, no. 12, pp. 1344-1359, 2010.

[42] C. Ivorra, C. García-Vicent, F. J. Chaves, D. Monleón, J. M. Morales, and E. Lurbe, "Metabolomic profiling in blood from umbilical cords of low birth weight newborns," Journal of Translational Medicine, vol. 10, no. 1, article 142, 2012.

[43] I. Tea, G. le Gall, A. Küster et al., "1H-NMR-based metabolic profiling of maternal and umbilical cord blood indicates altered materno-foetal nutrient exchange in preterm infants," PLos One, vol. 7, no. 1, article e29947, 2012.

[44] D. Favretto, E. Cosmi, E. Ragazzi et al., "Cord blood metabolomic profiling in intrauterine growth restriction," Analytical and Bioanalytical Chemistry, vol. 402, no. 3, pp. 1109-1121, 2012.

[45] B. H. Walsh, D. I. Broadhurst, R. Mandal et al., "The metabolomic profile of umbilical cord blood in neonatal hypoxic ischaemic encephalopathy," PLos One, vol. 7, no. 12, article e50520, 2012.

[46] G. Graça, S. Diaz, J. Pinto et al., "Can biofluids Metabolic profiling help us to improve health care during pregnancy?" Spectroscopy, vol. 27, no. 5-6, pp. 515-523, 2012. 


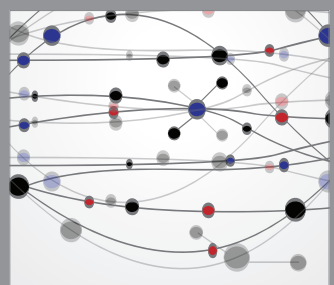

The Scientific World Journal
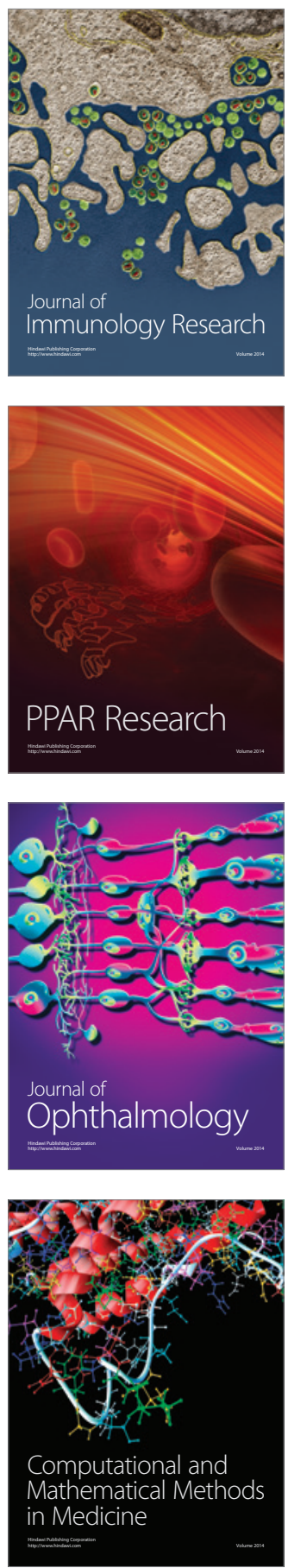

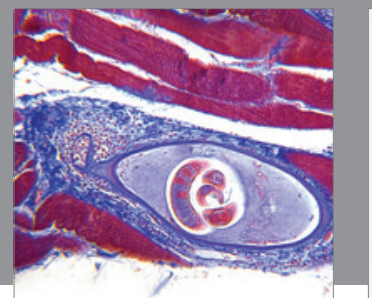

Gastroenterology

Research and Practice
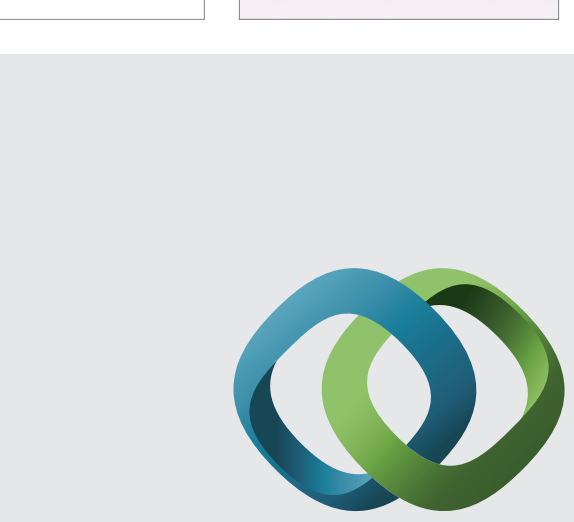

\section{Hindawi}

Submit your manuscripts at

http://www.hindawi.com
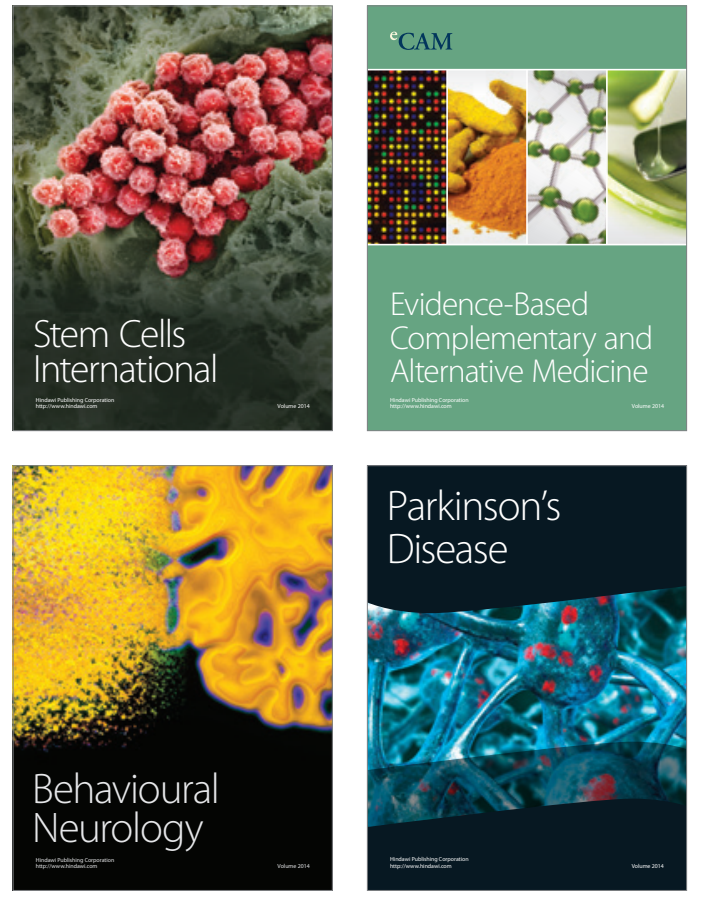
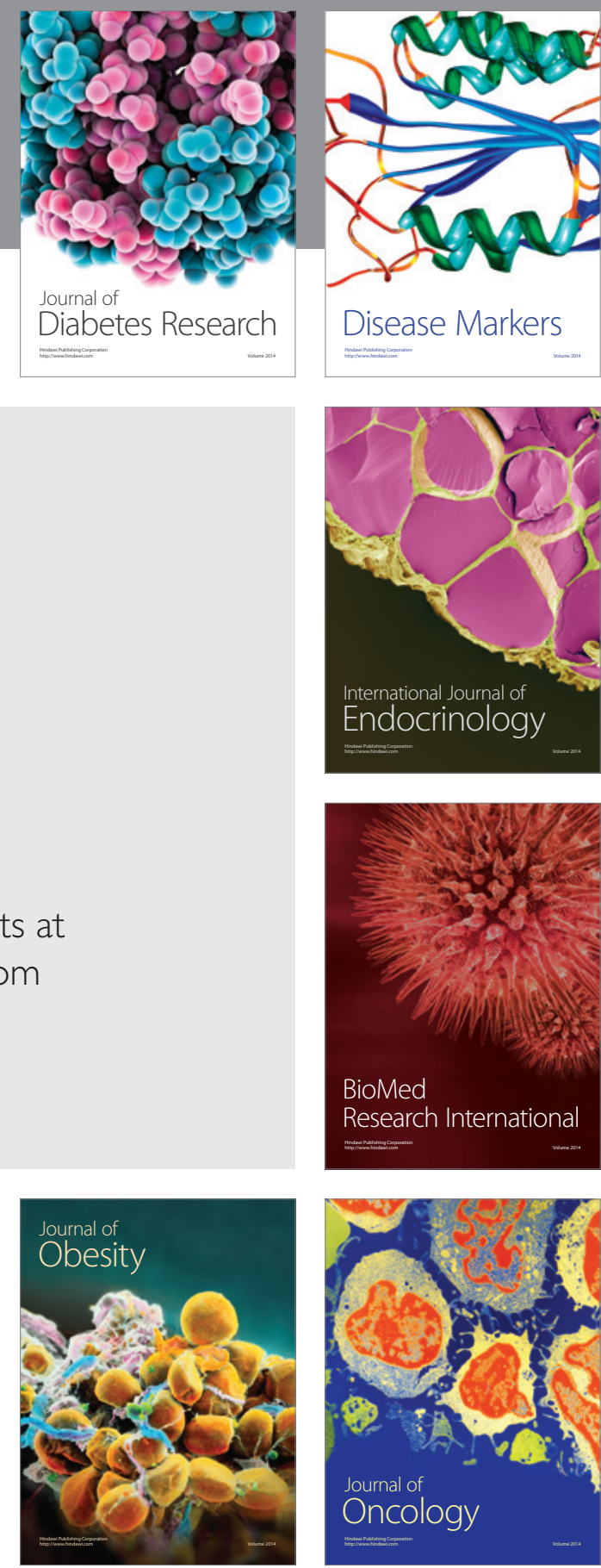

Disease Markers
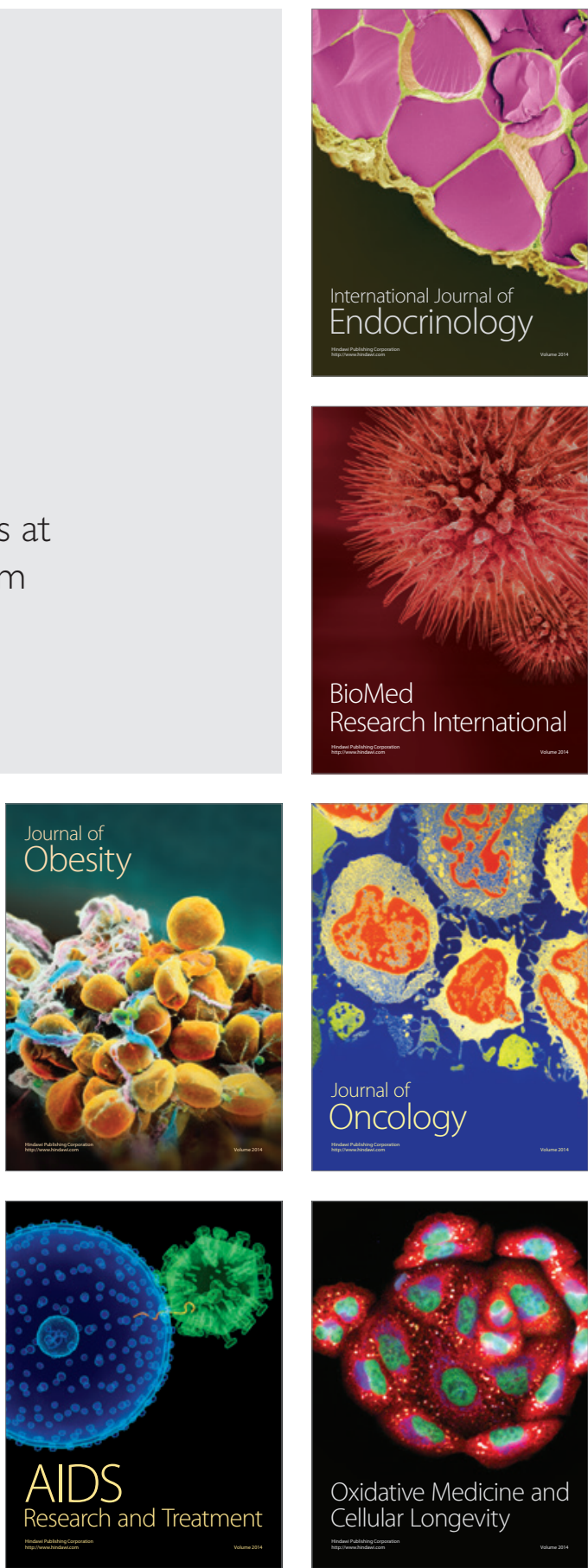